\title{
PEMANFAATAN LIMBAH PINUS MENJADI BIO PESTISIDA ASAP CAIR SEBAGAI SOLUSI ZERO LOSSES PINE FOREST DI DESA POGALAN KECAMATAN PAKIS
}

\author{
Dwi Adi Purnama1, Bella Azis Dewanti Putri², Nashtiti Aliafari ${ }^{3}$, Febri Wahyudi ${ }^{4}$, \\ Diora Ananda ${ }^{5}$ \\ 1,2,3,4Prodi Teknik Industri, Fakultas Teknologi Industri, Universitas Islam Indonesia \\ ${ }^{5}$ Prodi Teknik Kimia, Fakultas Teknologi Industri, Universitas Islam Indonesia \\ Yogyakarta
}

\begin{abstract}
ABSTRAK
Kawasan Hutan Pinus salah satunya berada di Desa Pogalan Kecamatan Pakis, Kabupaten Magelang Provinsi Jawa Tengah. Hutan Pinus Kragilan merupakan wisata yang di kelola oleh Balai Taman Nasional Gunung Merbabu dan masyarakat Desa Pogalan. Peningkatan pinus yang dihasilkan di Kabupaten Magelang, terutama di Desa Pogalan, Kecamatan Pakis dapat mengakibatkan peningkatan jumlah bunga dan daun pinus yang berserakan di daerah tersebut. Limbah hasil tumbuhan pinus seperti bunga dan daun pinus belum di tangani secara maksimal di daerah tersebut sehingga dapat menjadi penumpukan bunga dan daun pinus yang dapat berupa pencemaran lingkungan. Limbah pinus (bunga dan daun pinus) dapat dianfaatkan menjadi produk yang memiliki nilai sehingga dapat meningkatkan taraf ekonomi di daerah tersebut. Metode pelaksanaan yang dilakukan dalam kegiatan ini yang berupa pelatihan pengolahan limbah pinus (bunga dan daun) menggunakan metode filosofi Kaizen, yang meliputi tahap PDCA (Plan-Do-Check-Action). Filosofi Kaizen adalah proses manajemen yang berupa perbaikan terus-menerus. Hasil yang diperoleh berdasarkan metode PDCA, masyarakat dapat melakukan aktivitas program dan membuat bio pestisida asap cair yang akan digunakan untuk mengatasi permasalahan hama tanaman sayur di desa Pogalan.
\end{abstract}

Kata kunci: Limbah, pinus, bio pestisida, asap cair

\section{PENDAHULUAN}

Tumbuhan pinus merupakan salah satu tanaman yang memiliki nilai ekonomis tinggi. tumbuhan pinus secara morfologinya memiliki tujuh bagian, yaitu mulai dari akar, batang, tangkai, daun, bunga, buah dan biji. Limbah tumbuhan pinus seperti bunga dan daun pinus dapat dijadikan bahan pembuatan biopestisida.

Kawasan Hutan Pinus salah satunya berada di Desa Pogalan Kecamatan Pakis, Kabupaten Magelang Provinsi Jawa Tengah. Hutan Pinus Kragilan merupakan wisata yang di kelola oleh Balai Taman Nasional Gunung Merbabu dan masyarakat Desa Pogalan. Hutan Pinus Pogalan termasuk dalam wilayah Resort Wekas, Seksi Pengelolaan Taman Nasional wilayah II di Krogowanan (Anonim, 2016).
Peningkatan pinus yang dihasilkan di Kabupaten Magelang, terutama di Desa Pogalan, Kecamatan Pakis dapat mengakibatkan peningkatan jumlah bunga dan daun pinus yang berserakan di daerah tersebut. Limbah hasil tumbuhan pinus seperti bunga dan daun pinus belum di tangani secara maksimal di daerah tersebut sehingga dapat menjadi penumpukan bunga dan daun pinus yang dapat berupa pencemaran lingkungan. Limbah pinus (bunga dan daun pinus) dapat dianfaatkan menjadi produk yang memiliki nilai sehingga dapat meningkatkan taraf ekonomi di daerah tersebut. Asap cair dapat dibuat dengan memanfaatkan limbah tumbuhan yang digunakan untuk pertanian dalam perlindungan tanaman dari organisme pengganggu (Kompas, 2006). Asap cair merupakan larutan dari 
sebaran asap tumbuhan dengan mengembunkan asap hasil pirolisis (Wiyantono \& Minarni, 2009). Asap cair dapat diimplementasikan pada berbagai produk makanan atau pangan yang dapat dilakukan dengan berbagai metode, seperti pencampuran, pencelupan atau perendaman, penyuntikan, pencampuran asap cair pada air perebusan, dan penyemprotan (Budijanto, et. al., 2008).

Selain itu, permasalah hama merupakan masalah yang sering menggagalkan pertanian. Pada sistem pertanian, hama seperti ulat daun kubis, ulat kubis, ulat batang, dan lainnya yang dapat merusak tanaman. Karena keberadaanya dapat merusak tanaman dan mengurangi ketersediaan pangan, hama ulat sering dimusnahkan dengan cara yang umum digunakan yaitu penyemprotan pestisida kimia. Pestisida kimia dianggap sebagai solusi utama dalam mengendalikan hama ulat. Namun, perlu disadari bahwa penggunaan pestisida kimia dapat menimbulkan berbagai dampak negatif baik bagi lingkungan maupun bagi kesehatan.
Losses Pine Forest di Desa Pogalan Kecamatan Pakis".

Kegiatan ini dilakuakan dengan tujuan untuk mengurangi limbah pinus, serta melakukan pengolahan limbah pinus untuk mengatasi permasalahan hama sayuran. Terbentuknya masyarakat mandiri dan berdaya dalam mengatasi permasalahan potensi hutan pinus di Desa Pogalan, Pakis.

\section{METODE}

Metode pelaksanaan yang dilakukan dalam kegiatan ini yang berupa pelatihan pengolahan limbah pinus (bunga dan daun) menggunakan metode filosofi Kaizen, yang meliputi tahap PDCA (Plan-Do-Check-Action). Filosofi Kaizen adalah proses manajemen yang berupa perbaikan terus-menerus. Implementasi dari tahap PDCA ini adalah dengan dilakukannya tutorial/bimbingan terhadap masyarakat Desa Pogalan, Pakis. Berikut ini adalah: 2.1 Plan (Perencanaan)

Dalam usaha mencapai tujuan kegiatan, tahapan persiapan yang akan dilakukan oleh peneliti adalah sebagai berikut:

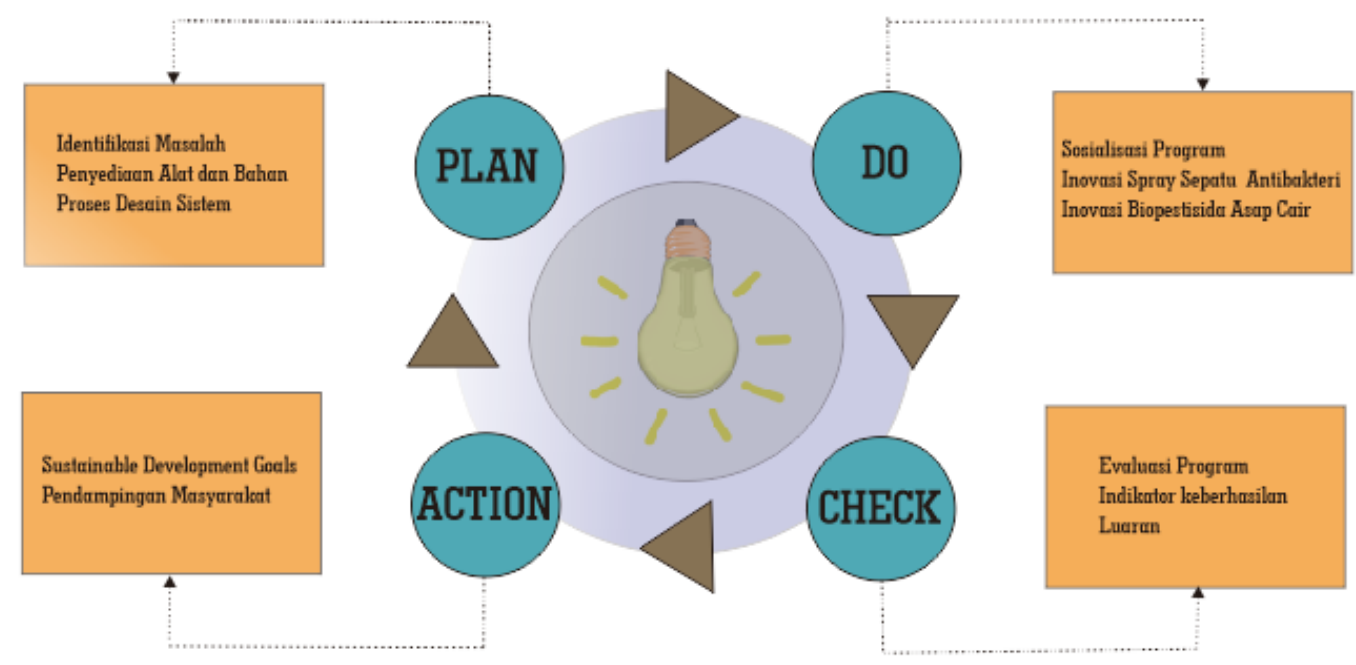

Gambar 1. Metode Pelaksanaan

Berdasarkan permasalah dan potensi tersebut, maka tim pelaksana Program Pengabdian Masyarakat berusaha untuk meningkatan kreativitas, memberikan bimbingan teknologi dan mendampingi warga Desa Pogalan. Usaha ini akan dilakukan melalui program "PICO SELF (Pine Cones Waste for Bio Ecological System) : Pemanfaatan Limbah Pinus menjadi Bio Pestisida Asap Cair sebagai Solusi Zero
2.1.1. Identifikasi Masalah dan Solusi Desa Pogalan adalah desa yang terletak di Kecamatan Pakis, Kabupaten Magelang. Permasalahan yang sering kali muncul yaitu sisa dari bagian pohon pinus seperti bunga maupun helai pinus menumpuk menjadi limbah dan terjadi setiap harinya, sedangkan masyarakat desa belum mengetahui pengolahan limbah pinus.

2.1.2. Penyediaan Alat dan Bahan 
Adapun alat dan bahan dalam pembuatan biopestisida asap cair sebagai berikut:

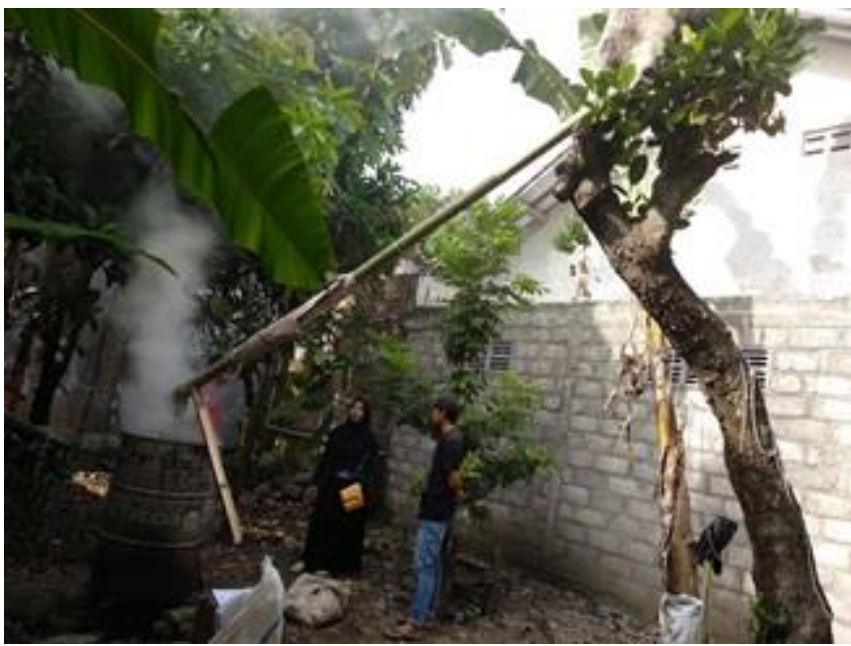

Gambar 2. Alat dan Bahan b. Materi pengantar Inovasi pembuatan bio pestisida asap cair menggunakan limbah pinus

c. Pemanfaatan hasil inovasi pembuatan bio pestisida

2. Program Inovasi Pembuatan Biopestisida Asap Cair dari Limbah Pinus

Kegiatan inovasi pembuatan bio pestisida asap cair dari limbah pinus ditujukan untuk Karang Taruna di Desa Pogalan. Pada kegiatan ini akan diberikan pelatihan pemanfaatan limbah pinus (bunga dan daun) menjadi bio pestisida asap cair menggunakan alat pirolisis. Bio Pestisida Asap Cair merupakan sebuah produk yang akan

2.1.3. Proses Desain Sistem

Adapun desain pembuatan biopestisida asap cair adalah sebagai berikut:

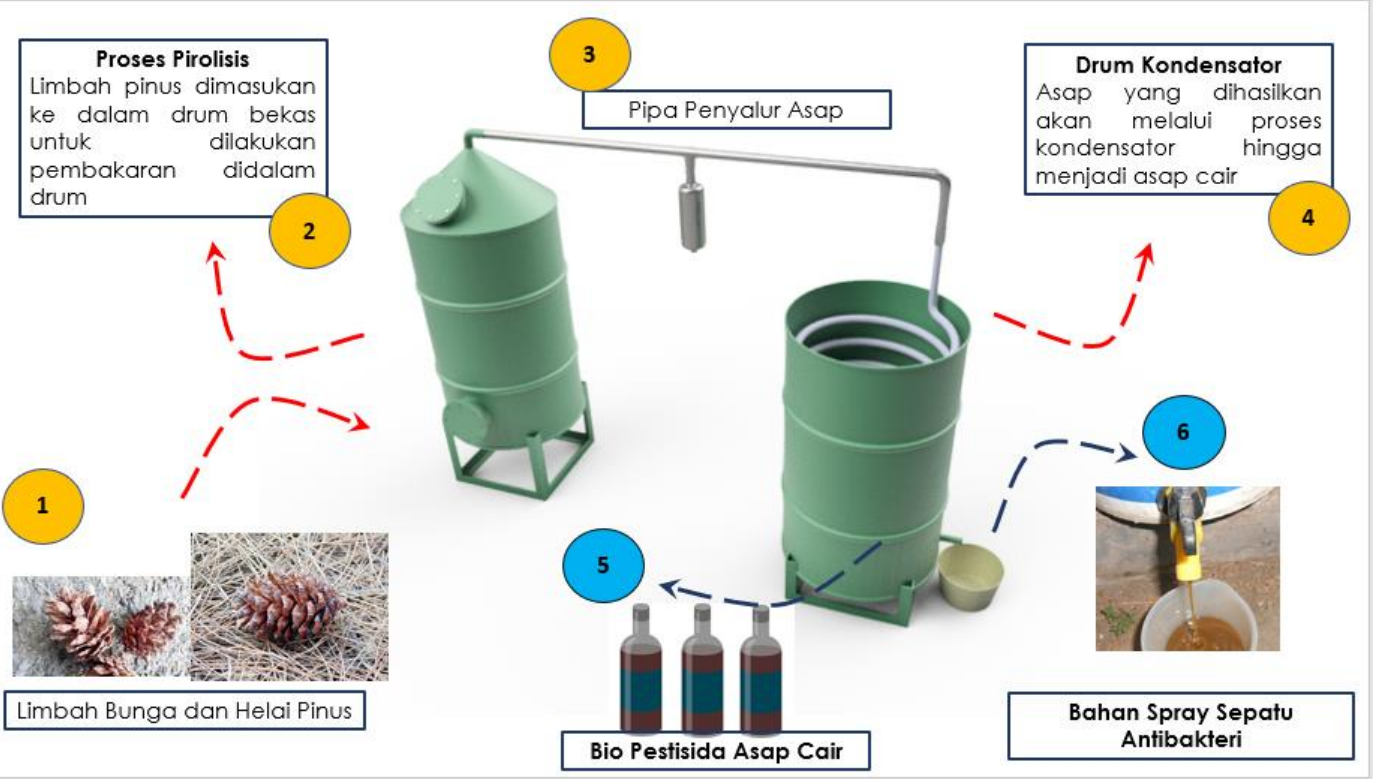

Gambar 3. Konsep Pembuatan Spray Antibakteri dan Bio Pestisida Asap Cair

\subsection{Do (Pelaksanaan)}

Setelah tahap plan selesai, maka tahapan yang akan dilakukan berikutnya adalah pelaksanaan kegiatan. Tahapan pelaksanaan yang akan dilakukan adalah sebagai berikut:

1. Sosialisasi Program

Sosialisasi program merupakan kegiatan pengenalan program yang akan dilakukan dengan metode berdiskusi mencakup: digunakan dalam mengatasi masalah hama dan dapat menggantikan pestisida kimia berbahaya. Pengolahan asap cair melalui Pirolisis. Pirolisis merupakan dekomposisi termokimia biomassa pada suhu antara 400 dan $650^{\circ} \mathrm{C}$ dengan tidak adanya $\mathrm{O} 2$ (Kasim, et. al.).

3. Pemantauan dan Implementasi Bio Pestisida Asap Cair

Pemantauan dilakukan setelah masyarakat diberikan bekal pelatihan sebelumnya. Kegiatan pembimbingan dan pendampingan selama satu bulan, 
sehingga diharapkan setelah dilakukan kegiatan ini masyarakat Desa Pogalan dapat mandiri menghasilkan biopestisida yang berasal dari limbah pinus dan dapat membantu mengatasi masalah hama dalam pertanian di desa tersebut. bio pestisida asap cair, agar selain diterapkan langsung produk ini dapat dipasarkan di masayrakat luar desa dan menjadi salah satu usaha baru bagi karang taruna Desa Pogalan dengan

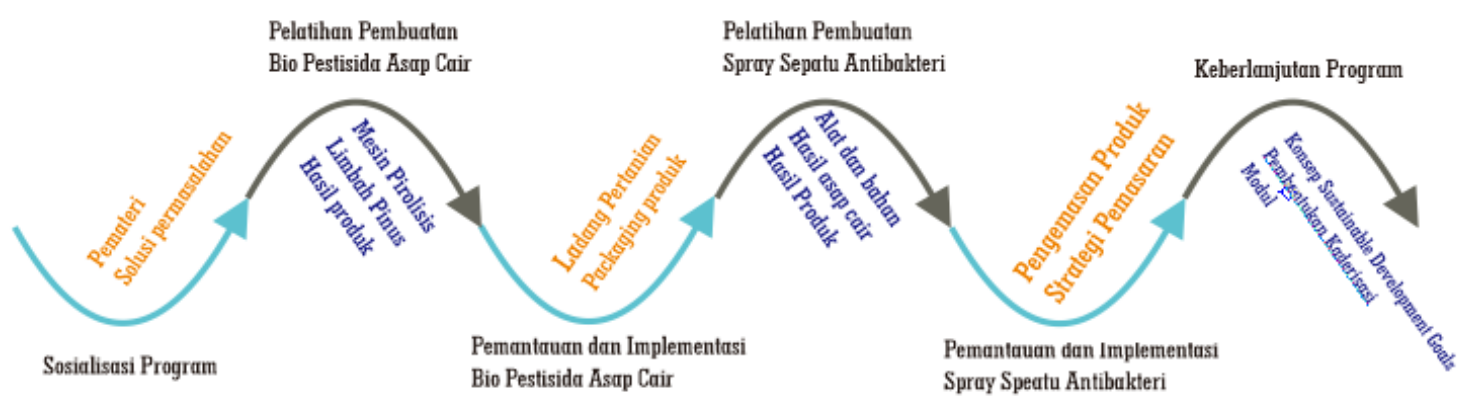

Gambar 4. Tahapan Pelaksanaan Program Menjadi Produk Bernilai

Implementasi bio pestisida asap cair yaitu secara langsung diterapkan pada ladang pertanian Desa Pogalan yang dapat menggantikan pestisida kimia dan memberantas hama tanaman. Selain itu, Karang Taruna diberikan bekal terhadap desain packaging produk memanfaatkan potensi daerah.

2.3. Check (Evaluasi)

Pada tahap ini dilakukan evaluasi setiap program dengan memastikan indikator program tercapai dan menghasilkan luaran yang diharapkan.

Tabel 1. Indikator dan Luaran

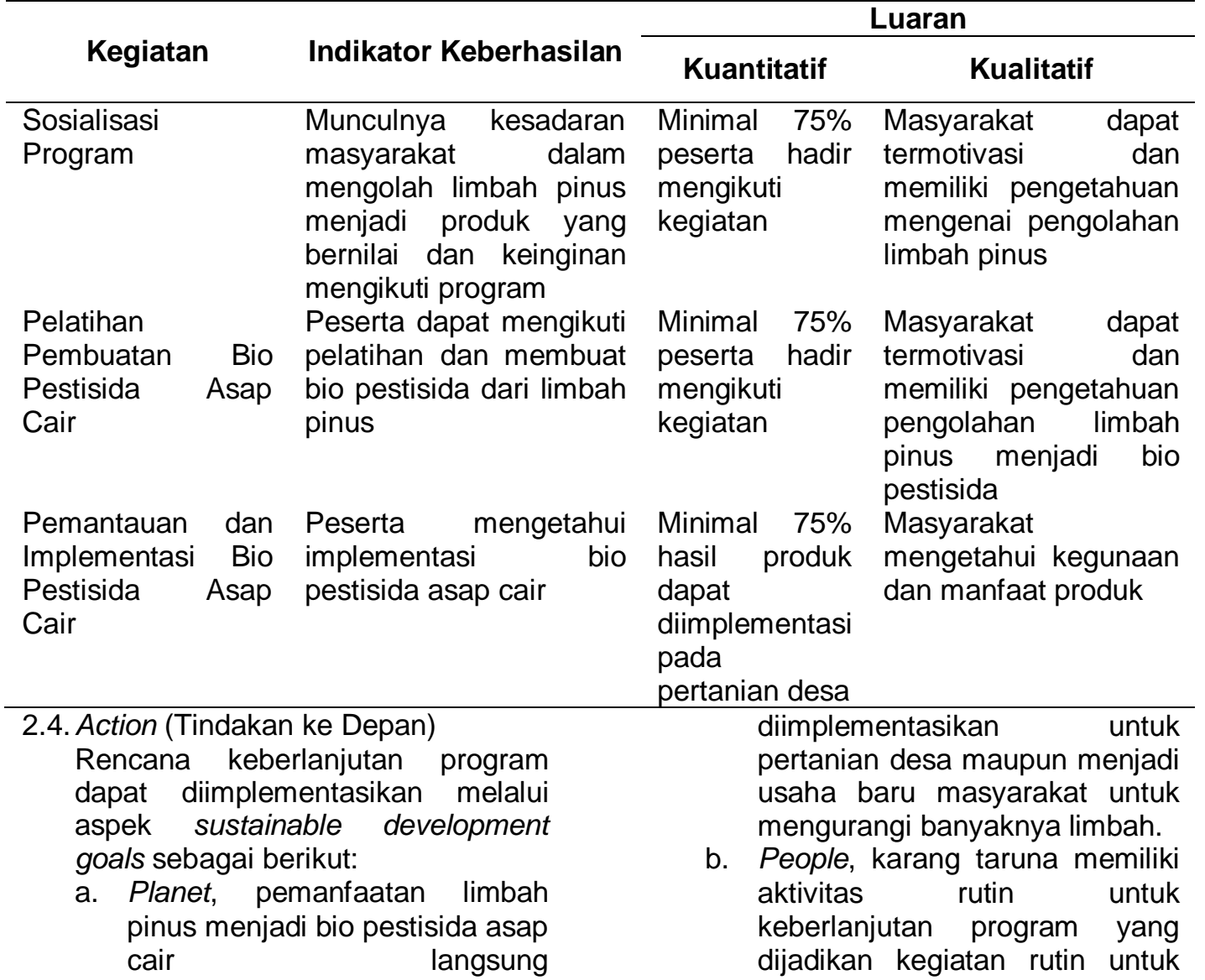


meningkatkan produktivitas dan mengatasi masalah limbah pinus yang berserakan setiap harinya.

c. Profit, hasil dari bio pestisida asap cair dapat menjadi usaha baru dengan minimum cost yang dikelurkan namun mendapatkan keuntungan dimana dapat dilakukan kerjasama pemasaran di petani daerah lain.

\section{HASIL DAN PEMBAHASAN}

Setelah berjalannya rangkaian program yang telah dilakukan di Desa Pogalan Kecamatan Pakis. Telah didapatkan beberapa hasil penyelesaian yaitu sebagai berikut:

Tabel 2. Ketercapaian Hasil

\begin{tabular}{|c|c|c|c|c|}
\hline \multirow[b]{2}{*}{ Kegiatan } & \multirow[b]{2}{*}{ Tujuan } & \multirow{2}{*}{$\begin{array}{l}\text { Indikator } \\
\text { Keberhasilan }\end{array}$} & \multicolumn{2}{|c|}{ Hasil Luaran } \\
\hline & & & Kuantitatif & Kualitatif \\
\hline \multirow[t]{3}{*}{$\begin{array}{l}\text { Pelatihan } \\
\text { Pembuatan } \\
\text { Bio Pestisida } \\
\text { Asap Cair }\end{array}$} & \multirow[t]{3}{*}{$\begin{array}{l}\text { Memberikan } \\
\text { pengetahuan } \\
\text { dan pelatihan } \\
\text { mengenai } \\
\text { pengolahan } \\
\text { limbah pinus } \\
\text { menjadi bio } \\
\text { pestisida untuk } \\
\text { penangkal hama } \\
\text { pada pertanian }\end{array}$} & \multirow[t]{3}{*}{$\begin{array}{l}\text { Peserta } \\
\text { mengikuti } \\
\text { pelatihan dan } \\
\text { dapat memahami } \\
\text { praktek dalam } \\
\text { membuat bio } \\
\text { pestisida asap } \\
\text { cair dari limbah } \\
\text { pinus }\end{array}$} & $\begin{array}{l}\text { Peserta yang } \\
\text { hadir } \\
\text { sebanyak } \\
77 \% \text { dari total } \\
\text { keseluruhan } \\
\text { populasi } \\
\text { petani } \\
\text { sebanyak } 35 \\
\text { petani dan } 8 \\
\text { non Petani. }\end{array}$ & $\begin{array}{l}\text { Antusiasme } \\
\text { masyarakat } \\
\text { dalam mengikuti } \\
\text { pelatihan } \\
\text { pembuatan bio } \\
\text { pestisida asap } \\
\text { cair. }\end{array}$ \\
\hline & & & $\begin{array}{l}\text { Total Peserta } \\
\text { yang } \\
\text { mengikuti } \\
\text { adalah } \\
\text { sebanyak } 43 \\
\text { orang. }\end{array}$ & $\begin{array}{l}\text { Masyarakat } \\
\text { dapat } \\
\text { termotivasi dan } \\
\text { memiliki } \\
\text { pengetahuan } \\
\text { pengolahan } \\
\text { limbah pinus } \\
\text { menjadi bio } \\
\text { pestisida }\end{array}$ \\
\hline & & & $\begin{array}{l}\text { Peserta yang } \\
\text { sangat yakin } \\
\text { memahami } \\
\text { proses } \\
\text { pembuatan } \\
\text { bio pestisida } \\
\text { sebanyak } \\
100 \% \text { (hasil } \\
\text { kuesioner) }\end{array}$ & $\begin{array}{l}\text { Masyarakat } \\
\text { mampu } \\
\text { menghasilkan } \\
\text { produk bio } \\
\text { pestisida yang } \\
\text { akan digunakan } \\
\text { sebagai } \\
\text { penangkal hama } \\
\text { pada lahan } \\
\text { pertanian } \\
\text { sendiri. }\end{array}$ \\
\hline \multirow[t]{3}{*}{$\begin{array}{l}\text { Pemantauan } \\
\text { dan } \\
\text { Implementasi } \\
\text { Bio Pestisida } \\
\text { Asap Cair }\end{array}$} & \multirow{3}{*}{$\begin{array}{l}\text { Memberikan } \\
\text { pengetahuan } \\
\text { mengenai } \\
\text { praktek cara } \\
\text { penggunaan bio } \\
\text { pestisida asap } \\
\text { cair pada lahan } \\
\text { pertanian }\end{array}$} & \multirow{3}{*}{$\begin{array}{l}\text { Peserta } \\
\text { mengetahui cara } \\
\text { implementasi bio } \\
\text { pestisida asap } \\
\text { cair pada lahan } \\
\text { pertanian. }\end{array}$} & $\begin{array}{l}\text { Peserta yang } \\
\text { hadir } \\
\text { sebanyak } \\
80 \% \text { dari total }\end{array}$ & $\begin{array}{l}\text { Masyarakat } \\
\text { mengetahui } \\
\text { kegunaan dan } \\
\text { manfaat produk. }\end{array}$ \\
\hline & & & $\begin{array}{ll}\text { keseluruhan } \\
\text { populasi } \\
\text { petani } \\
\text { sebanyak } 36 \\
\text { petani dan } & 10 \\
\text { non Petani. }\end{array}$ & $\begin{array}{l}\text { Masyarakat } \\
\text { dapat } \\
\text { melakukan } \\
\text { praktek } \\
\text { penggunaan bio } \\
\text { pestisida secara }\end{array}$ \\
\hline & & & $\begin{array}{l}\text { Total Peserta } \\
\text { yang }\end{array}$ & lahan pertanian. \\
\hline
\end{tabular}




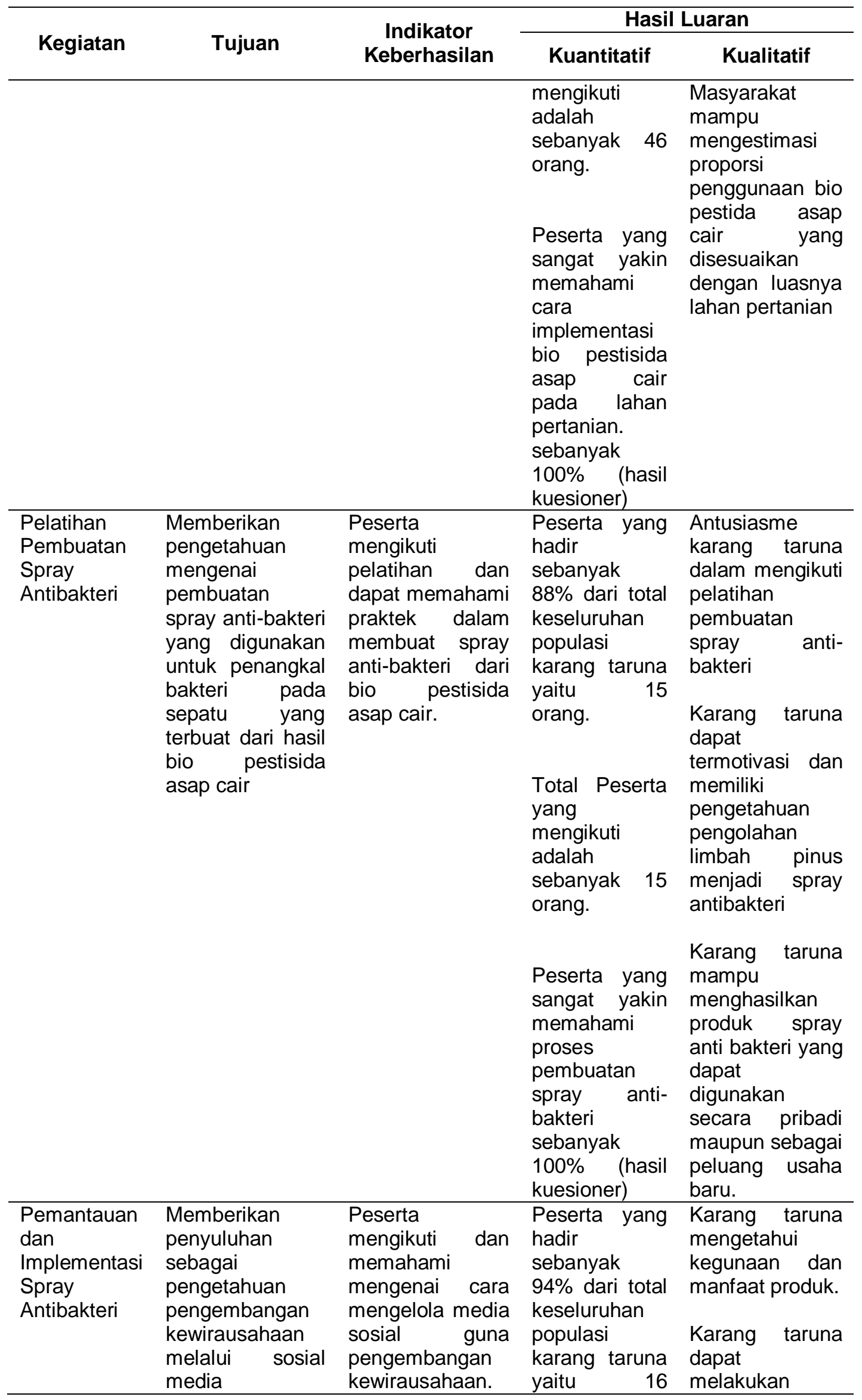




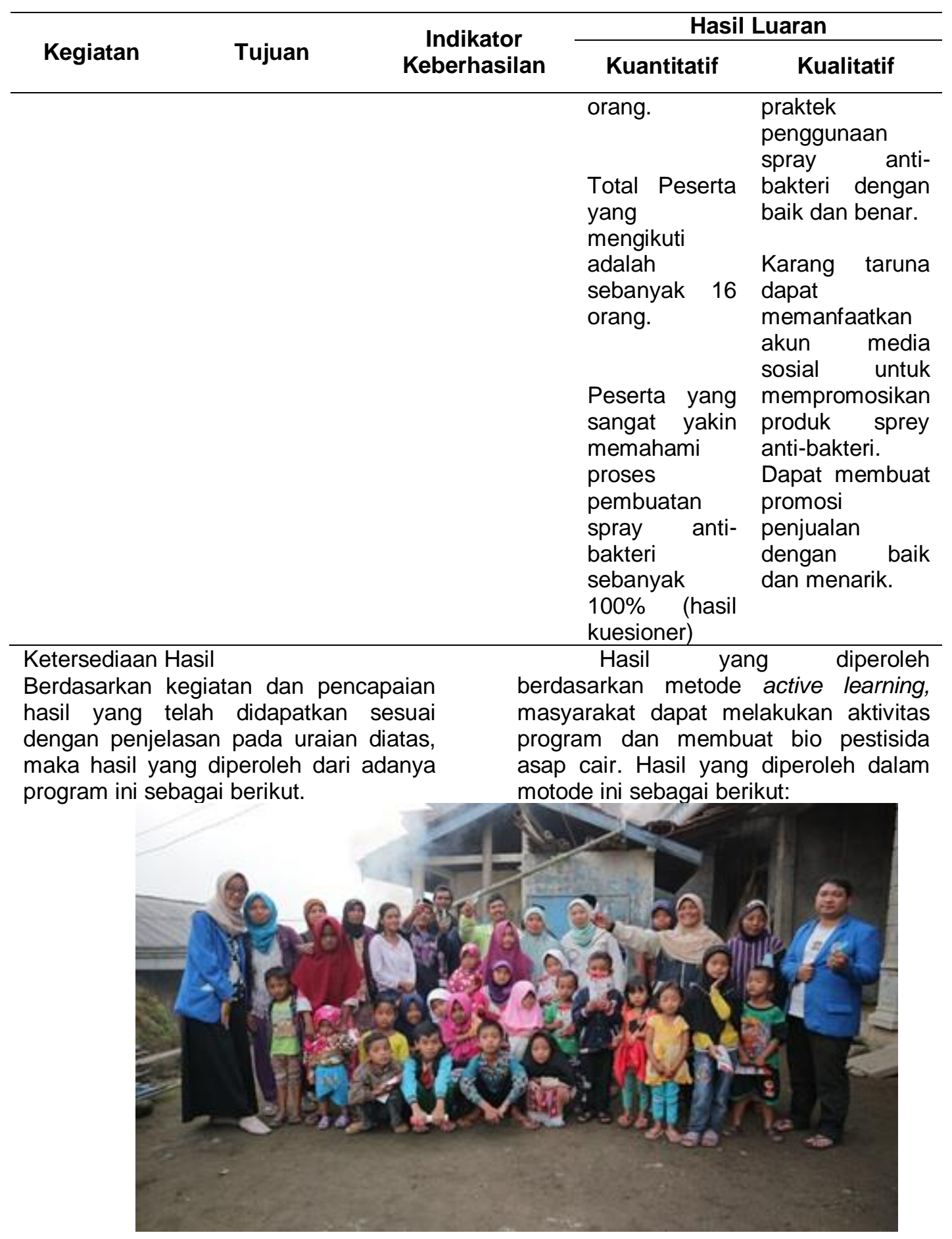



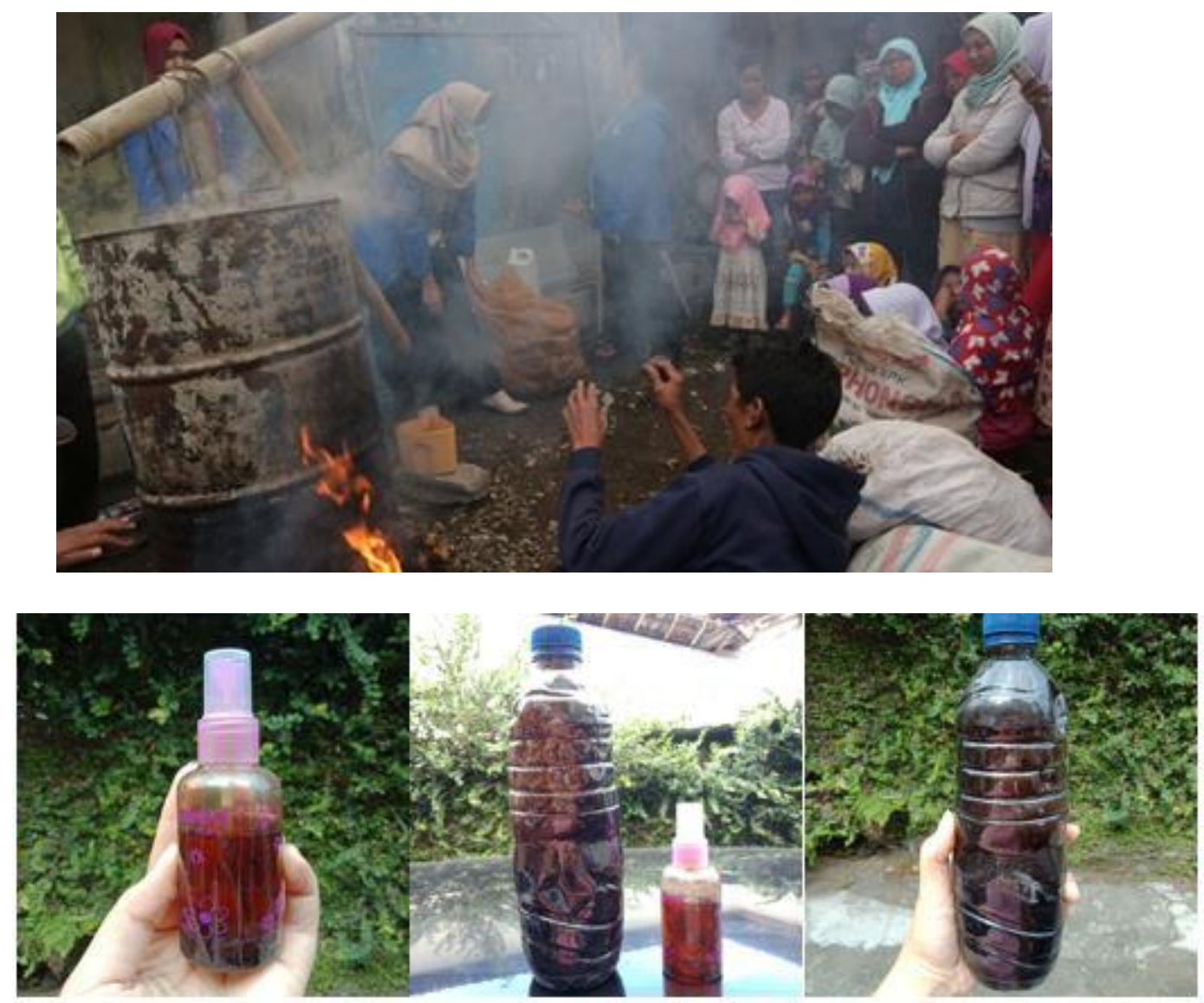

Gambar 5. Hasil Pelaksanaan Program

\section{KESIMPULAN}

Masyarakat Desa Pogalan Kecamatan Pakis mengetahui potensi daerah seperti pinus dan juga pemanfaatan limbah pinus untuk mengatasi permasalahan hama di tanaman sayur melalui program pembuatan bio pestisida asap cair dari limbah pinus. Sehingga, hasil bio pestisida asap cair dapat digunakan untuk menyelesaikan masalah hama tanaman sayuran.

\section{DAFTAR PUSTAKA}

Budijanto, Slamet; Hasbullah, Rokhani;

Prabawati, Sulusi; Setyadjit;

Sukarno; dan Zuraida, ita. 2008.

Identifikasi Dan Uji Keamanan Asap

Cair Tempurung Kelapa untuk
Produk Pangan. J.Pascapanen 5(1) 2008: 32-40.

Kasim, Fitriani; Fitrah, Arum Nur; Hambali, Erliza. Aplikasi Asap Cair pada Lateks. Jurnal PASTI Volume IX No 1, 28-34

Kompas. 2006. UGM Perkenalkan Asap Pengganti Formalin. (On-line). http://www.kompas.com./teknologi/ne ws.

Wiyantono and Minarni, Endang Wari. 2009. Kajian Potensi Asap Cair dalam mengendalikan Ulat Krop Kubis, Crocidolomia Pavonana Study On Potency Of Liquid Smoke Against The Cabbage Head Caterpillar, Crocidolomia Pavonana. Universitas Jenderal Soedirman. 